\title{
Anglicanism and Interventionism: Bishop Brent, The United States, and the British Empire in the First World War
}

\author{
by MICHAEL SNAPE \\ Durham University \\ E-mail: michael.snape@durham.ac.uk
}

Although largely overlooked by historians, the worldwide Anglican Communion proved to be a major force in mobilising support for the Allied cause throughout the First World War. This article examines the wartime career of Bishop Charles Henry Brent, a Canadian-born bishop of America's Protestant Episcopal Church, who is usually remembered as a missionary, an ecumenist, and as a campaigner against the international opium trade. This article revisits Brent's wartime career, illustrating his three-fold significance as a contemporary symbol of Episcopalian power and influence in the United States, as an epitome of Episcopalian Anglophilia, and as a morale-boosting presence in wartime Britain.

B ishop Charles Henry Brent (1862-1929) has usually been remembered as a missionary, an ecumenist, a devotional writer, and as the world's leading campaigner against the opium trade. ${ }^{1}$ On his death in Lausanne in March 1929, eighteen months after his portrait graced the cover of Time magazine, this apparently tireless and omnicompetent bishop was the most celebrated prelate in the Anglican

The author would like to thank Chaplain Nathan White (USAR) for his assistance in researching this article, and its anonymous reviewer for helpful comments upon it.

${ }^{1}$ See, for example, New York Times, 28 Mar. 1929, 27; Eleanor Slater, Charles Henry Brent: everybody's bishop, Milwaukee 1932; Eugene C. Bianchi, 'The ecumenical thought of Bishop Charles Henry Brent', Church History xxxiii (1964), 448-61; Frederick Ward Kates, "Lo, I come to do thy will, O God": an appreciation of Bishop Charles Henry Brent (1862-1929)', Anglican and Episcopal History (hereinafter cited as $A E H)$ xxviii (1959), 267-72; Mark D. Norbeck, 'The legacy of Charles Henry Brent', International Bulletin of Missionary Research, Oct. 1996, 163-8; and Frank E. Sugeno, 'Charles Henry Brent, apostle for unity', $A E H \operatorname{lxx}$ (2001), 75-9. 
Communion, a national figure in his adoptive United States, and a doyen of liberal Protestants the world over. The breadth of Brent's ecumenical vision, which even embraced wholehearted co-operation with Roman Catholics, was boldly enunciated at the 1910 World Missionary Conference in Edinburgh, ${ }^{2}$ and his willingness to facilitate co-operation between Protestants, Catholics and Jews in the American Expeditionary Forces (or AEF) during the First World War served as an early manifestation of America's interfaith (or 'tri-faith') ideal, one that would see its full flowering in the mid-twentieth century. ${ }^{3}$ However, Brent's wartime career was notable for reasons other than his religious latitude and foresight, reasons that substantially qualify Brent's image as an ecumenical statesman and avid internationalist. In fact, his role in the First World War reveals Brent's underlying identity as a fervent Anglophile, as a leading ecclesiastical advocate of American intervention on the side of the Allies, and as arguably the most influential bishop in the wartime Anglican Communion.

Brent's forgotten significance as a major religious figure in the years of the First World War stems from a chronic historiographical failure to recognise the broader religious dimensions of this global conflict. While studies of the importance and experience of global religious traditions and networks have emerged in the past decade, 4 the significance of worldwide Anglicanism remains a neglected theme, ignored (like Brent himself, despite his wartime profile in Great Britain) in standard histories of the Church of England in the First World War.5 Nevertheless, this was the first global conflict since the first Lambeth Conference met in 1867 , or since the term 'Anglican Communion' became current in the $185^{\mathrm{os}},{ }^{6}$ and the role of the Communion's Churches, provinces and dioceses

${ }^{2}$ Brian Stanley, The World Missionary Conference, Edinburgh, I9 Io, Grand Rapids 2009, 297.

3 David Mislin, 'One nation, three faiths: World War I and the shaping of "Protestant-Catholic-Jewish" America', Church History lxxxiv (2015), 828-62 at pp. 845-7; Will Herberg, Protestant, Catholic, Jew: an essay in American religious sociology, New York 1955; Kevin M. Schultz, Tri-faith America: how Catholics and Jews held postwar America to its Protestant promise, Oxford 2011.

4 Michael Snape, 'The Great War', in D. H. McLeod (ed.), The Cambridge history of Christianity: world Christianities c. I9I4- c. 2000, Cambridge 2006, 131-50; Adrian Gregory, 'Beliefs and religion', in Jay Winter (ed.), The Cambridge history of the First World War, III: Civil society, Cambridge, 2014, 418-44; Philip Jenkins, The great and holy war: how World War I changed religion for ever, Oxford 2014.

5 Albert Marrin, The last crusade: the Church of England in the First World War, Durham, NC 1974; Alan Wilkinson, The Church of England and the First World War, London 1978; Stuart Bell, 'The Church and the First World War', in Stephen G. Parker and Tom Lawson (eds), God and war: the Church of England and armed conflict in the twentieth century, Farnham-Burlington, VT 201 2, 33-59.

6 W. M. Jacob, The making of the Anglican Church worldwide, London 1997, 157. 
proved highly significant in many Anglophone countries and their dependencies. Unlike the Roman Catholic or Eastern Orthodox Churches, Anglicans were not pitted against each other by the war, and nor, as in the wrenching case of German Lutherans and their co-religionists in the United States, did recent migration from Europe require an Anglican diaspora to take up arms against its mother country. Clearly, and because of its British origins and heritage, Anglicanism was among the most significant transnational agents of religious mobilisation for the British and Allied cause. Although their conduct is liable to wild exaggeration and even gross caricature, 7 the Anglican hierarchy in Great Britain certainly lent strong and conspicuous support to the national war effort. Furthermore, and after conscription was introduced for mainland Britain in 1916, Anglicans constituted a smaller percentage of conscientious objectors than Britain's tiny minority of professed atheists. ${ }^{8}$ Even where Anglicanism was a minority denomination shorn of formal ties to the state, Anglican devotion to the empire was no less conspicuous. In the early stages of the war Anglicans were over-represented among the volunteers who flocked to the colours in Canada, Australia, Ireland and even Wales. ${ }^{9}$ Likewise, in the East African theatre of war, Frank Weston, the combative bishop of Zanzibar, played a major role in recruiting and leading the indigenous porters who were so vital to maintaining imperial forces in the field. ${ }^{10}$

The Protestant Episcopal Church in the United States was also conspicuously zealous in its support for the British cause, despite its distinctiveness within the 'loose collection of churches' that was the Anglican Communion at the turn of the twentieth century. ${ }^{11}$ Existing outside the British Empire, it was largely removed from the formative influences of Oxford and Cambridge, ${ }^{12}$ historically sensitive to suspicions of domination from England, and since its inception in 1789 it had modelled a very different ecclesiology from the Church of England. Partly rooted in the emphatically non-established Scottish Episcopal Church, its democratic temper and system of semi-elective conventions and synods stood in sharp contrast to

7 Gregory; 'Beliefs and religion', 432-3; Bell, 'The Church and the First World War', $57-8$.

8 Wilkinson, Church of England, 47.

9 Michael McKernan, Australian Churches at war: attitudes and activities of the major Churches (I9I4-I9I8), Sydney-Canberra 1980, 40, 161; Mark G. McGowan, "We are all involved in the same issue": Canada's English-speaking Catholics and the Great War', in Gordon L. Heath (ed.), Canadian Churches and the First World War, Eugene 2014, 34-74 at p. 65; Melissa Davidson, 'The Anglican Church and the Great War', in Heath, Canadian Churches, ${ }_{15}^{2-69}$ at p. 153; Davidson papers, Lambeth Palace Library, London, Ms 344, fos 201-4, 209, 235-6.

${ }^{10}$ H. Maynard Smith, Frank, bishop of Zanzibar, London 1926, ch. x.

11 Mark Chapman, Anglican theology, Edinburgh 2012, 185.

${ }^{12}$ Jacob, Making of the Anglican Church, 168-9. 
the medieval structures of episcopal government inherited by the established Church of England. ${ }^{13}$ None the less, in the latter there was an enduring sense that the Protestant Episcopal Church was very much a daughter Church, and the Church of England's Guardian and Church Times newspapers reported on its affairs on a weekly basis. Still, how much was understood about the Protestant Episcopal Church is open to question. For example, in June 1918 Brent received a telling letter from The Challenge, a relatively new and progressive Church of England weekly which prided itself on an informed and enlightened outlook. Written on behalf of no less a figure than William Temple, it grandly announced that the paper was 'very anxious to get into closer touch with the American Episcopal Church', and asked Brent to recommend potential correspondents. It also posed such basic questions as to what Episcopalian newspapers to read, and which parties they represented. ${ }^{14}$ In a characteristically courteous and helpful reply, Brent supplied a brief resumé of the main Episcopalian publications but ended by suggesting that the staff of The Challenge might find the more secular and comprehensive Literary Digest more helpful and instructive. ${ }^{15}$

However unfamiliar it may have remained to Anglicans in Great Britain, by 1914 the Protestant Episcopal Church was undoubtedly an important player in the life of the Communion. The deliberations of its General Convention of 1886, for example, had supplied the basis of the ChicagoLambeth Quadrilateral of 1888 , the first 'international definition of what constituted Anglicanism' ${ }^{16}$ It was also a major force in Anglican missionary work, which had been boosted in the Pacific after the Spanish-American War of $1898,{ }^{17}$ and with the help of the Church Emigration Society it provided a natural home for many of the one million emigrants from Great Britain who entered the United States between 1891 and $1914^{18}$ To British and even Canadian expatriates, the Protestant Episcopal Church also offered a fruitful career path. William T. Manning, for example, who was born in Northamptonshire in 1866, left for the United States in 1882, and was Rector of Trinity Church, New York, by 1914 and bishop of New York by 1921. Although Manning had emigrated while still a layman, in a striking illustration of the global mobility offered to the

${ }^{13}$ Colin Podmore, 'A tale of two Churches: the ecclesiologies of the Episcopal Church and the Church of England compared', International Journal for the Study of the Christian Church viii (2008), 124-54.

${ }^{14}$ Ethel M. Barton to Charles Brent, 1 June 1918 , Brent papers, Library of Congress, Washington, DC, Manuscript Division, box 15.

15 Brent to Ethel M. Barton, 6 June 1918 , ibid..

16 Chapman, Anglican theology, 193.

17 Kevin Ward, A history of global Anglicanism, Cambridge 20o6, 60.

18 Guardian, 23 Mar. 1916, 261; Ben J. Wattenberg (ed.), The statistical history of the United States from colonial times to the present, New York 1976, 105, series c 89-119. 
clergyman by the Anglican Communion, and of the tangled skein of loyalties that could ensue, in February 1918 Edward Dering Evans, Rector of St Luke's, Baltimore, wrote to the bishop of London seeking help in securing a chaplain's commission in the British army or - alternatively - in the New Zealand Expeditionary Force. Backed by his vestry, and armed with the endorsement of Bishop John G. Murray of Maryland, Evans tendered this convoluted but revealing explanation:

The late Bishop of Norwich ordained me in 1904 and I was with Canon TupperCarey at Lowestoft and Canon Hepher at Newcastle-on-Tyne until [in] the Mission of Help to New Zealand in 1910 I accepted a parish in the Diocese of Dunedin, and was called to St. Luke's Baltimore in August, 1914. Not realising that the war was to be a long one, and despairing of being sent with the N.Z. [Expeditionary] Forces, I came here ... I am ashamed that I have not volunteered sooner, but now that there are two able assistant curates and the parish is well provided for, I feel that I can leave it in answer to my country's call. ${ }^{19}$

Brent himself stands as perhaps the ultimate example of these successful clerical migrants to the United States. Born in Newcastle, Ontario, in April 1 862, Brent's father was an Anglican clergyman and a first-generation immigrant from England, his mother a descendant of Loyalist refugees from New York. ${ }^{20}$ Although the infusion of immigrants from Canada was smaller than the stream from Great Britain around the turn of the twentieth century, it was still considerable, as around 450,00o Canadians entered the United States in the quarter century prior to the First World War. ${ }^{21}$ While Anglicans represented a smaller proportion of the Canadian population, comprising around 15 per cent of all Canadians in 1914 as opposed to two-thirds of all Britons, ${ }^{22}$ there was already a well-established tradition of Anglican clergymen moving across the porous border between Canada and the United States in search of employment, ${ }^{23}$ a situation that brought Brent to the State of New York in 1886 while still in deacon's orders. As Alexander C. Zabriskie emphasised in his concise biography of 1947 , Brent's move to St Paul's Church, Buffalo, was entirely pragmatic: with no opportunities available in the diocese of Toronto, 'it was circumstance rather than conscience or preference that sent [Brent] there. He had not the least intention of remaining permanently under

${ }^{19}$ E. D. Evans to A. F. Winnington-Ingram, bishop of London, 7 Feb. 1918, Brent papers, box 15 .

${ }_{20}$ Alexander C. Zabriskie, Bishop Brent: crusader for Christian unity, Philadelphia 1947, $15^{-1} 7$.

${ }^{21}$ Wattenberg, Statistical history, 107 , series c 89-119.

${ }_{22}$ Davidson, 'Anglican Church', 153; C. D. Field, “"The faith society"? Quantifying religious belonging in Edwardian Britain, 1901-1914', Journal of Religious History xxxvii (2013), 39-63 at p. 62.

${ }^{23}$ Joseph Hardwick, An Anglican British world: the Church of England and the expansion of the settler empire, c. I790-I860, Manchester 2014, 174-82. 
the American flag; rather he looked forward to returning to a Canadian country parish within a few years'. ${ }^{24}$ In fact, it took a further appointment, as associate rector of St Stephen's Mission in the slums of Boston, to persuade Brent to take out his naturalisation papers in 1891 , and even then he appears to have maintained dual citizenship. ${ }^{25}$ In the event, his years in Boston served to reinforce Brent's links with Great Britain, for there he developed a formative relationship with the Society of St John the Evangelist (the Cowley Fathers), a connection that would take him to England on his very first overseas trip in November $1891 .{ }^{26}$

Significantly, Brent joined the Protestant Episcopal Church as America's role in the world was expanding, and as the Church itself was bidding for national pre-eminence. This aspiration was boldly expressed by William Reed Huntington, Rector of Grace Church, New York, in the Bedell Lectures at Kenyon College (an Episcopalian college in Gambier, Ohio) in 1897. Published the following year as A national Church, the title page of this manifesto bore the de facto national motto $E$ pluribus unum. According to Huntington, the Protestant Episcopal Church had the breadth and therefore the potential to become a truly national and catholic American Church, a goal that could be realised by leading a mission of reconciliation among American Protestants which would command respect as the work of 'the historic Church of the English-speaking peoples'. ${ }^{27}$ Thus, as Huntington saw it, and as America entered the lists as a great power, 'The Episcopal Church in this new world stands, at the present moment, at the parting of the way. After a century of infancy, a century of childhood, and a century of adolescence, she has come at last to her majority, and reports for duty. ${ }^{28}$ Although lacking in numbers (in 1916 it ranked as America's ninth largest denomination ${ }^{29}$ ) the Protestant Episcopal Church possessed enormous wealth in relation to its size and, in what has been described as America's 'great age of Episcocratic supremacy',30 it also enjoyed unrivalled social prestige and cultural cachet. Despite the generally Loyalist leanings of the Anglican clergy during the Revolutionary War, Anglicanism had been well represented among the Founding Fathers and it had been the faith of George Washington - and, by 1916 , of no fewer than seven of his twenty-six successors as president, a tally unrivalled by any other denomination..$^{{ }^{1}}$ The connection between the Protestant Episcopal Church, national institutions, and America's

\footnotetext{
24 Zabriskie, Bishop Brent, 22.

25 Ibid. 22, 32-3.

26 Ibid. $25^{-31 .}$

27 William Reed Huntington, A national Church, New York 1898, $71 . \quad 28$ Ibid.

${ }^{29}$ Bureau of the Census, Religious bodies, r9 I6: part I: summary and general tables, Washington, DC 1919, table 6, 33.

$3^{\circ}$ Kit Konolige and Frederica Konolige, The power of their glory: America's ruling class, the Episcopalians, New York 1978, 359 .

$3^{1} \mathrm{http}: / /$ www.pewforum.org/2009/01/15/the-religious-affiliations-of-us-presi-
} dents/. 
political and social elite was no less apparent in its ascendancy in the armed forces. For decades prior to the First World War, 'a disproportionate number of Episcopal priests served as Army chaplains', ${ }^{32}$ a situation that was also true of the US Navy. ${ }^{33}$ Moreover, and despite the notional constraints of the First Amendment, the Protestant Episcopal Church was all but established at the service academies of West Point and Annapolis, the principal nurseries of the professional officer corps.34 For all its progressives and Social Gospellers, 35 and its missionary work among Native, African and Japanese Americans, the Church was also firmly identified with the cream of American society, counting families such as the Astors, the Morgans, the Vanderbilts and the Hearsts among its glitterati. ${ }^{6}$ In a telling bon mot ascribed to William T. Manning, when asked if salvation could be found outside the Protestant Episcopal Church, Manning replied 'Perhaps so, but no gentleman would avail himself of it.'37

A cultural and racial factor that also favoured the Protestant Episcopal Church at the turn of the twentieth century was the currency of 'AngloSaxonism', the Anglophone analogue of Pan-Germanism and PanSlavism. Emphasising the common heritage and destiny of Great Britain and the United States, this was both symptom and cause of their rapprochement after the American Civil War. $3^{8}$ Notwithstanding its vaunted roots in the Scottish Episcopal Church, as quintessentially Anglo-Saxon and reliably Anglophile the Protestant Episcopal Church basked in these atmospherics, and produced leading Anglo-Saxonists of its own. Chief among them was the naval officer, historian and maritime strategist Alfred Thayer Mahan, whose celebrity as 'the Prophet of Sea Power' on both sides of the Atlantic largely stemmed from his providential reading of national histories and national destinies, a reading that was not simply Anglophile in character but deeply coloured by his own Episcopalian faith and background. 39 Described by a recent biographer as 'a paternalistic Anglo-Saxon supremacist' $4^{\circ}$ and a high-profile supporter of the overseas missionary work of the

$3^{2}$ Michael E. Shay, Sky pilots: the Yankee division chaplains in World War I, Columbia $2014,6$.

33 Clifford M. Drury, The history of the Chaplain Corps: United States Navy, I: I778-1939, Washington, DC 1949, $117,255$.

34 Michael Snape, God and Uncle Sam: religion and America's armed forces in World War II, Woodbridge $2015,15^{8-62 .}$

35 Andrew Preston, Sword of the spirit, shield of faith: religion in American war and diplomacy, New York, 201 2, 315-16.

${ }^{36} \mathrm{http} / / /$ www.newyorker.com/magazine/ 1986/o4/28/standing-out-there-on-theissues.

37 Konolige and Konolige, The power of their glory, 368.

$3^{8}$ Stuart Anderson, Race and rapprochement: Anglo-Saxonism and Anglo-American relations, I895-1904, East Brunswick 1981; Dominic Lieven, Towards the flame: empire, war and the end of tsarist Russia, London 2015, 22-4.

39 Suzanne Geissler, God and sea power: the influence of religion on Alfred Thayer Mahan, Annapolis 2015, 96-129. 
Protestant Episcopal Church, the Church of England weekly newspaper the Guardian devoted a reverent obituary to 'Admiral Mahan' on his death in 1914 , observing that he had died 'in the midst of a great war in which his deductions from history have received the most signal vindication' ${ }^{4}{ }^{1}$

With the acquisition of an American overseas empire in all but name as a result of the Spanish-American War, the role of the Protestant Episcopal Church moved beyond acting as a rallying point for American Protestants and asserting its influence at the seat of national government (an assertion that took ever more tangible form as the project of the National Cathedral in Washington progressed from 1893). $4^{2}$ With the Philippines now an American protectorate, and the duty of the United States, in the alleged words of President McKinley, being 'to educate the Filipinos, and uplift and civilize and Christianize them',43 the Protestant Episcopal Church reacted swiftly to the new situation. In October 1901 its triennial General Convention, then meeting in San Francisco, added to the American missionary surge by electing Charles Henry Brent as bishop of the Philippine Islands. 44 However, and in recognition of political imperatives, he was to be kept on a tight rein. Plucked from his domestic missionary work in Boston, Brent was sent not to a new diocese, but to a new missionary district of the Protestant Episcopal Church.45 Furthermore, Bishop Arthur Hall of Vermont, his English-born mentor and a former Cowley Father, $4^{6}$ made it clear at Brent's consecration that his duties, though not precluding the conversion of Catholic, Muslim or pagan Filipinos, were primarily geared towards their new, self-styled American guardians and mentors. 47 Although distinguished by his conciliatory approach to Roman Catholicism, and lauded for his pioneering work as a missionary on Luzon, Brent's freedom of action was therefore circumscribed from the outset. In the wake of a Filipino insurrection that had seen the deaths of 4,ooo Americans and tens of thousands of Filipinos, Brent worked well within the parameters set by President Theodore Roosevelt and Governor William Howard Taft. Hence, he dutifully eschewed confrontation with the Philippines' Roman Catholic majority, $4^{8}$ and subordinated the evangelisation of other indigenes to his work with Americans (and, for that matter, even Britons). As Brent explained in an unsolicited report to the new archbishop of Canterbury, Randall Davidson, in July 1904:

$4^{1}$ Guardian, 3 Dec. 1914, 1317.

43 Preston, Sword of the spirit, 156 .

44 Zabriskie, Bishop Brent, 44-6. 45 Bureau of the Census, Religious bodies I9I6: part
description, and statistics, Washington, DC 1919, 613.

$4^{6}$ http://anglicanhistory.org/usa/acahall/hill 193 o.html.

47 Zabriskie, Bishop Brent, 48.
$4^{2}$ http://cathedral.org/history/timeline/.

$4^{8}$ Preston, Sword of the spirit, 227-9. 
To sum up the situation, the religious problem among English speaking people in the Philippines is not radically different from what it is elsewhere; the obstacles with which we have to contend are the familiar ones reinforced by the enervating influences of perpetual summer on the physical side, and the absence of that moral stimulation that is a concomitant of Anglo-Saxon civilisation. It cannot be repeated too often that our earliest and best efforts must be devoted to the American and English population, as is the case in all the British colonies that I have visited in the Orient. A judge said to me only yesterday in commenting on this aspect of the work: 'If the spiritual needs of Americans in the Philippines are to be cared for as they should be, the whole time of the bishop should be devoted to them'. 49

In keeping with his varied role as the chief custodian of American morals in the Philippines, $5^{\circ}$ in July 1903 Brent received his first official government appointment when he was chosen to join the fact-finding Philippine Opium Committee, $5^{1}$ tasked with investigating the regulatory systems in place across Asia for controlling the opium trade. A litmus test of American pretensions to a new and improving form of colonialism, and a cause dear to the heart of the nation's powerful missionary lobby, the complex struggle against the international opium trade absorbed a good deal of Brent's energies. $5^{2}$ After serving on the committee, he represented the United States at the International Opium Commission at Shanghai in 1909, and at the 1911 Opium Conference at The Hague, presiding at both assemblies. 53 He was also able to use his connections within the Anglican Communion to recruit the support of the archbishops of York and Canterbury, who exerted sympathetic pressure on the British government.54 However, such efforts not only reflected the transnational influence and reach of the Anglican Communion but also signalled America's emergent role as an arbiter in Asian affairs, 55 one that had been underlined by President Theodore Roosevelt's involvement in ending the Russo-Japanese War of 1904-5.

Closely identified with US interests in Asia, Brent also acted as a trusted personal agent of successive American presidents. Prior to his departure for the archipelago, and as the representative of the Protestant Episcopal Church, he was received by Roosevelt in Washington and his journey to the Philippines (via Europe and Rome) was made in the entourage of Governor William Howard Taft. $5^{6}$ In fact, and although a Unitarian, Taft later frequented Brent's services in Manila, as did William Cameron Forbes, a subsequent governor who was likewise not an Episcopalian. 57

49 'Religious conditions in the Philippine Islands', Davidson papers, Ms 97, fo. 13.

$5^{\circ}$ Ian Tyrrell, Reforming the world: the creation of America's moral empire, Princeton 2010 , 126-8; Zabriskie, Bishop Brent, 74-6.

$5^{2}$ Tyrrell, Reforming the world, 149-59.

53 Zabriskie, Bishop Brent, 74-6, 99-107; Arthur Stanwood Pier, American apostles to the Philippines, Boston 1950, 145-9; The Times, 28 Mar. 1929, 19.

54 Tyrrell, Reforming the world, $15^{8-9 .}$

$5^{6}$ Zabriskie, Bishop Brent, $5^{\mathrm{o}}$. 
Such connections were to prove invaluable; not only did Taft succeed Roosevelt as president in 1909, but the rotation through the Philippines of scores of senior military officers and civil servants created a large reservoir of influential friends and future patrons, a factor that helps to account for the rags-to-riches quality of Brent's public career. While in the Philippines, for example, Brent confirmed Major General Leonard Wood, a future Chief of Staff and later champion of the preparedness movement. $5^{8}$ More significantly, in January 1910 Brent baptised and confirmed Brigadier General John J. Pershing, who in 1917 was to be Woodrow Wilson's choice as the commander-in-chief of the AEF. From this position of trust, Brent had the difficult task of consoling Pershing after his wife and three children died in a house fire in San Francisco in 1915.59 Nevertheless, Pershing would testify that it was Brent's example as a missionary in the Philippines that lay at the root of his later patronage, writing: 'Because of his devotion to the ideals and obligations of Christianity, his great abilities, his warm, human character, he was in my estimation an outstanding missionary, Christian and leader. It was always an inspiration to be associated with him.' ${ }^{60}$ Not only did Brent's role in the Philippines bring him considerable kudos and critical connections in public life, but it also burnished his prospects in the Protestant Episcopal Church. As Ian Tyrrell has pithily put it, 'Partly because Brent impressed presidents, he impressed his fellow bishops. ${ }^{61}$

The response of the Protestant Episcopal Church to the outbreak of war in Europe, and to the First World War as it unfolded, has received very little attention in the developing literature on American religion and the First World War. ${ }^{62}$ This is not surprising, as its role is easily obscured by the kaleidoscopic reactions of so many other denominations (at least 200 by 1916 , according to the Census Bureau $)^{63}$ and was overshadowed by the public melodrama that was the presidential career of America's most famous Presbyterian, Woodrow Wilson. Nevertheless, the Episcopalian response was distinctive, going well beyond the default, broadly pro-Allied but

$5^{8}$ Ibid. 77 .

59 Earl F. Stover, Up from handymen: the United States army chaplaincy, I 865-1920, Honolulu 2004, 189,226 n. 13.

61 Tyrrell, Reforming the world, 197.

${ }^{62}$ See, for example, John F. Piper, The American Churches in World War I, Athens, GA 1985; Clifford Putney, Muscular Christianity: manhood and sports in Protestant America, I 880-1920, Cambridge, MA 2001, 162-94; Richard M. Gamble, The war for righteousness: progressive Christianity, the Great War, and the rise of the messianic nation, Wilmington 2003; Rich Schweitzer, The cross and the trenches: religious faith and doubt among British and American Great War soldiers, Westport 2003; Jonathan H. Ebel, Faith in the fight: religion and the American soldier in the Great War, Princeton 2010; Preston, Sword of the spirit, 233-90; and Gordon L. Heath (ed.), American Churches and the First World War, Eugene 2016.

63 Religious bodies, I9I 6: part II, 14 . 
ultimately neutralist position adopted by other Anglophone denominations. ${ }^{6}$ Significantly, this fact was not lost on inter-war commentators, not least the pacifist polemicist Ray H. Abrams, who wrote with some vehemence in his highly influential Preachers present arms of 1933:

Among the denominations, the Protestant Episcopal Church in this country, since its founding, has been a thoroughly English organization, having many ties that bind it to the mother church in England. Its clergy are constantly passing back and forth between the two countries. It is generally appraised as a church of society, it maintains an air of aristocracy, and has within its ranks those who parade their titles and English connections ... At the time of the war numerous wealthy bankers, like the Morgans, either belonged to this church or had Episcopalian associations. Hence, with a few notable exceptions, the Episcopalian clergy, steeped in English traditions and culture, and, in general, on the side of the vested interests, simply acted in accord with the conditioning and habit-patterns already well established. Moreover, the Episcopalians, more than any others, have been traditionally tied up with various military organizations and patriotic orders, either through chaplains or social affiliations. ${ }^{6}$

While Abrams's judgement was symptomatic of the bitter and recriminatory mood of inter-war, isolationist, Depression-hit America, it was by no means wide of the mark - for Episcopalians did respond with conspicuous zeal to the plight of France, and the siren call of the Mother Country, long before the United States entered the First World War on 6 April 1917. In February 1915, for example, the dean of New York, William M. Grosvenor, wrote to the editor of the Guardian from the Cathedral of St John the Divine:

Your splendid courage; your calmness and sincerity; your efforts to go on as usual; the service that your Fleet is rendering to the commerce of the world; your loyalty to your treaties and your pledges - all that England has done and is doing to-day, for the preservation of truth and freedom and the Faith of Christ, wins our deep regard and our profound admiration ... I cannot speak for the American Church, but I can interpret the hearts of many of her sons when I send this brief and inadequate greeting of affection and courage to all who care to read it. Our prayers are for the peace of Christ in all the world, and for the safety and the restored prosperity of the great Anglo-Saxon race. ${ }^{66}$

Later that year the Church Times acknowledged the 'deep and unselfish sympathy with the cause of the Allies' expressed by churchmen in the United States, but at the same time worried that the robust stance of Episcopalians might prove counterproductive in a still-neutral nation, warning that 'We

\footnotetext{
64 Preston, Sword of the spirit, 247; David Hein and Gardiner H. Shattuck, The Episcopalians, New York 2004, 105.

65 Ray H. Abrams, Preachers present arms, 2nd edn, Eugene, 2009, 31.

66 Guardian, 25 Feb. $1915,172$.
} 
must not have it thought that the Anglican ideal of Catholicism is bound up with England', and that 'No greater blow could be struck at the American Church than to let it be represented as a sort of English Lutheranism.' ${ }^{6} 7$

Although geographically remote from the war as it unfolded, Brent followed its course with intense personal interest. From its outbreak, he ensured that a daily digest of war news (received via the United States and Reuter's News Agency in Shanghai) was communicated by telegraph and telephone from Manila to his mission station at Bontoc, in the northern highlands of Luzon. There, it was shared with a community of Belgian Roman Catholic missionaries, whose anxiety and despair affected him deeply. ${ }^{68}$ In combination with his Canadian background, Loyalist heritage and British connections, the effect was to move Brent into a position of forthright opposition to American neutrality, and of growing antipathy towards President Wilson. ${ }^{69}$ Eventually, the context of a global war, and his desire to be closer to its European cockpit, even led Brent to forswear his much-vaunted attachment to the Philippines. Twice elected bishop of Washington, $7^{\circ}$ and elected bishop of New Jersey as recently as May $1914,7^{11}$ he had consistently declined these calls to return to America, insisting that the Philippines deserved priority. ${ }^{2}$ However, such resolve had melted away by the time that he was elected bishop of Western New York, where he had begun his American ministry,73 in September 1917. As events were to prove, Brent's election presented a golden opportunity for him to be nearer the seat of war, and he prevailed upon the Standing Committee of the diocese to grant him indefinite leave for the duration as a condition of his acceptance. 74

By this point, of course, America was already at war, but Brent had immersed himself in the conflict long before the United States became a belligerent. Sent on sick leave to the United States in March 1916, Brent's affliction (namely the heart complaint that ultimately killed him75) did not prevent him from undertaking a prolonged and frenetic round of activity after his arrival. Returning to Canada to settle his brother's estate, in June 1916 Brent wrote to Archbishop Davidson reporting that 'Things are sad and disorganized there', and expressing dismay and disgust at the 'systematic exploitation by French and Belgian prostitutes' of Canadian soldiers in Europe. Nevertheless, he reaffirmed his trenchant position on the war: in August he was 'to go as chaplain to the training

67 Church Times, 8 Oct. 1915, 353 .

68 Zabriskie, Bishop Brent, $112-13$; Pier, American apostles, 149.

69 Zabriskie, Bishop Brent, $116-17$. $\quad 7^{0}$ New York Times, 4 Aug. 19o8, 8.

$7^{1}$ Ibid. 7 May 1914, 20.

$7^{2}$ Brent to Davidson, Whitsunday 19o8, Davidson papers, Ms 139, fo. 44 .

73 The Times, 29 Mar. 1919, 19.

74 Zabriskie, Bishop Brent, $121-2$; Church Times, 4Jan. 1918, 12.

75 Zabriskie, Bishop Brent, $113^{-14}$. 
camp at Plattsburg', New York, which had become the centrepiece of America's preparedness movement, and was planning to go to Europe that winter, having notified the Chaplain-General of the British army, Bishop John Taylor Smith, to that effect. As Brent confided to Davidson:

Of course I do not want to do anything that would not be of real service and sometimes I feel that my desire to help my friends and the cause with which I do not hesitate to identify myself magnifies in my eyes the possibility of my being of any real use. At any rate, you will always have my earnest thought and my prayers. $7^{6}$

Having gathered at Plattsburg with Leonard Wood, his old associate, and other kindred spirits, 77 Brent wrote to Mrs Davidson that September, rejoicing in the news that Bishop Henry Montgomery, Secretary of the SPG and former bishop of Tasmania, and Huyshe Yeatman-Biggs, bishop of Worcester, were to represent the Church of England at the impending General Convention in St Louis, Missouri. Although problems had been posed by 'war conditions', and by the competing demands of the Church of England's National Mission of Repentance and Hope, Davidson chose them in response to an invitation by the presiding bishop, Daniel Sylvester Tuttle (who, having been consecrated in 1867 , enjoyed the distinction of being 'the senior prelate in order of Consecration of the whole Anglican Communion') $.7^{8}$ As Brent saw the situation, 'It is a great satisfaction to us to have them for General Convention which would not seem complete now without representatives of the English Episcopate.' However, Brent did not confine his remarks to ecclesiastical matters. Although mildly critical of the execution of the leaders of the Easter Rising and of Sir Roger Casement, which he viewed as 'a strategic blunder', he rejoiced that Irish disaffection was the exception that proved a very different rule: 'The loyalty of Canada to the Empire is magnificent. Indeed I feel that one of the good results of the war will be the true consolidation of the British Empire.' Brent ended his letter on a familiar note, and with a dig at Wilson's commitment to internationalism and collective security, a commitment that the president had aired in a speech before the League to Enforce Peace: 'In spite of our neutral administration', Brent insisted, 'the heart of our nation is sound. There are those of us who steadily claim that the Allies are the League to Enforce Peace and as such we are openly and always for them and their principles.'79

$7^{6}$ Brent to Davidson, 20 June 1916, Davidson papers, Ms 379, fos $54^{-7}$.

77 Brent to Davidson, 16 Aug. 1916, ibid. fo. 63 .

$7^{8}$ Church Times, 1 Sept. 1916, 167 ; Guardian, 27 July 1916, 654.

79 Brent to Edith Davidson, 14 Sept. 1916 , Davidson papers, Ms 379, fos 64-6; Patrick Renshaw, The Longman companion to America in the era of the two World Wars, London 1996 , $84^{-} 5$. 
In the event, the proceedings at the General Convention set the scene for a reciprocal visit of American churchmen, vindicating the Guardian's intuition that the visit of the English bishops would 'form yet another link in the ever-strengthening chain of kindly associations between Anglicans of the Old World and the New' ${ }^{80}$ On arrival in the United States, the bishop of Worcester was feted by his co-religionists, and he preached or spoke in New York, Washington, Harvard and Boston. ${ }^{{ }^{1}}$ On his return, he told Davidson that his welcome had been 'extraordinarily cordial and sustained', ${ }^{82}$ and informed the clergy and laity of his diocese that 'Every day brought new ideas, new methods, new friends, and I can never forget the cordiality of the welcome which the Episcopal Church gave to the Church of England as represented by me, nor the sympathy for the cause of the Allies which was shown by almost every educated person I met.' 83 For his part, and though he deemed Americans brash and blustering, and Bishop Tuttle vulgar and condescending, ${ }^{84}$ Bishop Montgomery concurred that Episcopalians were unanimous and outspoken in their pro-Allied sympathies. As he caricatured their conversation in a waspish diary of his visit:

'Bishop Montgomery, I want to shake hands with you. I want to introduce myself to you. I come from the third largest city in the world ... I could shew you the finest view in the world. And our Church, it has the sixth largest communicants' roll in the United States. Bishop Montgomery, I want you to know that that our hearts are with you in the war. ${ }^{8}{ }_{5}$

Even Tuttle was not lacking in this respect, welcoming Montgomery, the bishop of Worcester and three Canadian delegates to 'a Joint Meeting of both Houses', where he 'went out of his way in very bold words to assure us that our Cause had the whole-hearted sympathy of every one they represented'. ${ }^{86}$ Indeed, General Convention passed a formal 'resolution of sympathy with the Mother Church' (namely the Church of England, rather than the Scottish Episcopal Church) which ran:

This Convention embraces the opportunity of the presence among us of several distinguished members of the Anglican Episcopate to give expression to its heartfelt sympathy with the venerable and beloved Church of England in the great tribulation through which she is passing. The Church from whom we are sprung, and to whose fostering care in our early history we owe so much, must ever be dear to our hearts. We cannot but rejoice in her prosperity and grieve in her adversity. Her

8 o Guardian, 7 Sept. 1916, 749 .

${ }^{81}$ H. Yeatman-Biggs, American addresses 1916 , London 1917, $15-47$.

82 Ibid., note to Randall Davidson in Lambeth Palace Library copy.

83 Guardian, 7 Dec. 1916, $105^{\circ}$.

$8_{4}$ Montgomery papers, Lambeth Palace Library, Ms 4540, fos ${ }^{1} 54^{-} 5$.

85 Ibid. fo. 163 . 
burdens and sorrows and losses must of necessity weigh heavily on us also. We cannot be unmoved when her heart is wrung with anguish. And so we ask her to accept this utterance of our love and sympathy in this time of her trial, and beg to assure her that our prayers are constantly ascending to Almighty God on her behalf, in humble supplication that in this 'great fight of afflictions' she may be endued with unfailing faith and girded about with omnipotent grace, and that the course of events may soon enjoy once more the blessings of peace - a peace deeply and securely founded in liberty and justice. ${ }^{87}$

If generally underwhelmed by the quality of leadership in the Protestant Episcopal Church, in a private report to Archbishop Davidson on his visit to the United States, Montgomery identified Brent as a bishop of exceptional talent and charisma: 'Bishop Brent is always an outstanding figure ... He is looked up to immensely. He can fill any building. He is always forceful and deeply spiritual.' 88 Furthermore, and even in a Church distinguished by its pro-British stance, Brent's zeal for the Allied cause was conspicuous. As Montgomery noted of their meeting with the Churchman's Club in Baltimore that November: 'Brent of course was excellent and wholly pro-ally, “Christians couldn't be neutral on moral questions, Honour first, safety afterwards." 89 By this point, Brent had already notified Davidson that General Convention had shown its English visitors how 'unneutral the heart of America' was, and had resolved to send a delegation of its own to Great Britain, $9^{\circ}$ ostensibly to help with the work of the National Mission and regardless of the fact that such a gesture 'would be misrepresented in American-German newspapers as un-neutral'.91 Further good news followed in November; Brent had been selected as one of the delegation and would sail early in the New Year. Better still, Canadian 'friends' had been busy on his behalf, and he had been 'empowered to render such service as may be possible' to the Canadian Expeditionary Force during the course of his visit. $9^{2}$

As it was anticipated that Brent could supply 'wise guidance on Missionary matters', his visit to Europe in the early months of 1917 began in a suitably low key, 93 being welcomed by the Guardian newspaper as 'always a persona grata to Churchmen in this country'.94 However, and having agreed to support Yeatman-Biggs in 'a Missionary Week' in the diocese of Worcester,95 the course of international affairs intervened

\footnotetext{
87 Guardian, 7 Dec. 1916, 1062.

89 Ibid. fo. 176 .

$9^{\circ}$ Brent to Davidson, 2o Oct. 1916, Davidson papers, Ms 379, fos 68-9.

$9^{1}$ Montgomery papers, MS 4540, fos $159^{-60}$.

$9^{2}$ Brent to Davidson, 14 Nov. 1916, ibid. fos $70-1$.

93 Davidson to Brent, 6 Oct. 1916, ibid. fo. 67. Brent's diary of this European visit is missing. See Alice Gunning to R. B. Ogilby, 5 Sept. 1929, Brent papers, box 57.

94 Guardian, 1 Feb. 1917, 78.

95 Davidson to Brent, 21 Nov. 1916, Davidson papers, Ms 379, fo. 75 .
} 
dramatically. By the end of January, events were moving strongly in Brent's (and Great Britain's) favour. After a ten-month lull, on $3^{1}$ January Germany resumed unrestricted submarine warfare, a ruthless strategy that had previously caused the sinking of the Lusitania in May 1915 and a development which led President Wilson to cut diplomatic relations three days later. On Monday 5 February, and from the relative obscurity of the English Midlands, the Birmingham Daily Gazette reported on a sermon given by Brent in Kidderminster parish church the previous day. Describing Brent as 'the representative of the American Episcopal Church in connection with the National Mission', it continued:

Referring to the present attitude of America on the war, [Brent] said he exulted that America had redeemed her honour and had declared herself the foe of the foes of the human race ... Neutrality was at times a necessity with nations, but where great moral principles were at stake, and justice, truth and righteousness had been deliberately and ruthlessly trampled under foot, neutrality was an impossibility ... America was all right at heart, even if at times her head had been wrong. $9^{6}$

The Birmingham Daily Post carried a further report on 'Bishop Brent of the Philippine Islands' on the very same day, this time describing the proceedings of a War Loan rally in Dudley the previous evening. Here, the eponymous visitor had added a personal appeal to that of the Minister of Pensions, George Nicoll Barnes. Pre-empting America's formal declaration of war by two months, Brent had declared that 'He was proud that he was an American citizen, and still prouder that he had never been a neutral ... now the two nations would march together to a peace with victory.' 97

Given such utterances, it did not take long for the outspoken bishop to claw his way out of the pages of the provincial press, his breakthrough coming with his scheduled sermon at Westminster Abbey the following Sunday, 11 February. Preached before a congregation that included the archbishop of Canterbury and the Lord Chancellor, the sermon confirmed and amplified Brent's position as 'an unofficial Ambassador of the people of America to the people of England' ${ }^{8}{ }^{8}$ It was printed in full in the Guardian and the Church Times later that week.99 The Scotsman newspaper provided an in-depth report the very next day. Not known for its sympathy for the Church of England, especially over the thorny issue of army chaplaincy, ${ }^{100}$ its tone was nevertheless one of avid approval.

$9^{6}$ Birmingham Daily Gazette, 5 Feb. 1917, 5 .

97 Birmingham Daily Post, 5 Feb. $1917,7$.

99 Ibid. 131; Church Times, 16 Feb. 1917, 157.

100 David Coulter, “'Garrisoning the nation's soul”: Calvinism, Douglas Haig and Scottish Presbyterian chaplaincy on the Western Front', in Michael Snape and Edward Madigan (eds), The clergy in khaki: new perspectives on British army chaplaincy in the First World War, Farnham-Burlington, VT 2013, 75-93 at pp. 83-4. 
Significantly, Brent's homily had commenced with a declaration of profound attachment and admiration for Great Britain:

[He] said that although a citizen of a sister nation, he came to them as no alien - a thousand ties bound himself and his nation to this country. It would be presumption of him, coming from a country in the height of prosperity, to try to teach those who, day by day, were laying treasure and human lives upon a reeking altar in order that they might be true to their ideals and pay their debt of love to the God of righteousness ... It was no flattery for him to say that the British nation was teaching the world to-day, and also unborn nations, such lessons as men needed, and which having learned, they treasured. ${ }^{101}$

Invoking Abraham Lincoln, 'world patriot', and the example of Alan Seeger, the American volunteer, Foreign Legionnaire and soldier-poet who had died on the Somme on 4 July $1916,{ }^{102}$ Brent declared that America had at last reached the point of no return. Once again preempting its declaration of war, Brent averred that:

It is not a case of ships; it is a case of righteousness. America is fighting with all the power of her moral life in order that, eventually, there may be a peace with victory over the foes of the human race who have ravaged Belgium and insulted her people, who massacred a million Armenians, who desolated Serbia and Poland with ruthless hands, who persist in slaughter and premeditated murder, who intimidate small nations and violate international relations. That is the root cause why America stands to-day where she does. ${ }^{103}$

Two days later, another War Loan meeting, this time in Derby, rang with Brent's words, and especially his 'foes of the human race' trope. This was echoed by Derby's MP, Sir William Collins, who was quick to claim a connection with the hero of the hour from his pre-war role as a 'British plenipotentiary' on the opium problem. ${ }^{104}$

It was, therefore, with ample justification that Davidson assured Brent on 12 March that 'The effect of your visit to this country has been considerable.' ${ }^{105}$ Indeed, and following America's declaration of war, it seems that some of his British admirers believed that Brent had been instrumental in hastening American entry. For example, on 12 April J. H. Greig wrote from Hartlebury rectory in the diocese of Worcester:

I must send you a line of sympathy in this great move that your country has made. Of all the 100.0oo.ooos $[\mathrm{sic}]$ of your great republic no one will be more delighted

\footnotetext{
101 Scotsman, 12 Feb. $1917,6$.

102 Church Times, 16 Feb. 1917, 157; https://www.poetryfoundation.org/poems-andpoets/poets/detail/alan-seeger.

${ }_{104}$ Derby Daily Telegraph, 14 Feb. $1917,2$.

105 Davidson to Brent, 12 Mar. 1917 , Davidson papers, Ms 379, fo. 74 .
} 
than you! I know that you were burning for this step to be taken, and how much your influence and adequacy have helped it forward. ${ }^{106}$

However, the rise of Brent as a wartime star in Great Britain was temporarily stalled by his anticipated visit to France, Brent leaving for the Western Front after preaching in Manchester Cathedral on 25 February. ${ }^{107} \mathrm{~A}$ week later he wrote a vivid 'private letter about Verdun' to Mrs Davidson, pronouncing the fortress city to be 'as sacred a spot to every lover of liberty as Gettysburg'. ${ }^{108}$ Later, he called upon the American Ambulance Hospital at Neuilly, whose volunteers specialised in facial reconstruction, and chatted with the British military attaché in Paris before heading to the British sector as guest of the Anglican Deputy Chaplain-General of the British Expeditionary Force (BEF), Bishop Llewellyn Henry Gwynne of Khartoum. Though still perplexed by the fact that 'Germany is at war with us, though we refuse to be at war with Germany', Brent was by this stage firmly convinced that the hand of God was at work all around him, writing to Archbishop Davidson on 19 March, the day before Wilson's cabinet concluded that war was inevitable:

Since I came to France I have had some very dark days - without a glimmer. Nothing seemed certain: everything was a query. But to-night it is as though the Spirit of God were really in control of this chaos, reshaping life and pressing on humanity with irresistible force. There must be moments at least when one must stand still and watch the glory of God go by. ${ }^{109}$

In light of Brent's allusion to Elijah, America's declaration of war gave this self-styled prophet of American intervention a role almost as portentous as that Old Testament prophet: 'Behold, I will send you Elijah the prophet before the coming of the great and dreadful day of the Lord.'1 10 Within days of America's declaration of war on 6 April 1917, Good Friday, a service of dedication had been organised by the American embassy in collaboration with various American organisations in London, ${ }^{111}$ and Brent's stature, reputation and availability 'solved any difficulty there might otherwise have been as to a preacher'. ${ }^{112}$ In what was then an unprecedented gesture, St Paul's Cathedral was placed at the disposal of London's American community by the dean and chapter as a 'token of the British nation's gratification'. ${ }^{113}$ Originally, the American plan had been for a

106 J. H. Greig to Brent, 12 Apr. 1917 , Brent papers, box 14.

${ }_{107}$ Church Times, 23 February 1917, 170.

108 Brent to Edith Davidson, 5 Mar. 1917 , Brent papers, box 52; Davidson to Brent, 12 Mar. 1917, Davidson papers, Ms 379, fo. 74 .

109 Brent to Davidson, 19 Mar. 1917 , Davidson papers, Ms 379 , fos $75^{-8}$.

110 Malachi iv. 5 .

112 Church Times, 27 Apr. 1917, 360.

113 Nottingham Evening Post, 12 Apr. 1917, 2. 
great patriotic gathering at the Albert Hall, but this was set aside in favour of a religious service, a decision which the Church Times deemed 'worthy of the spirit in which America enters the war'. ${ }^{114}$ Undoubtedly, Brent's homily at St Paul's Cathedral on 'America Day' (or 'Dedication Day' as the Church Times preferred to call it) was one of the most significant sermons to be preached in Britain during more than four years of war. As sources, such wartime sermons have proved problematic. When not simply ignored by historians on the unspoken premise that "no one listens to vicars', ${ }^{115}$ and following a pattern set by their secularist and pacifist detractors in the inter-war years, ${ }^{116}$ it has been common for interested historians to cite them with a careless selectivity - often with an eye to their shock value for readers of today, and with little or no consideration of their currency, reception or significance at the time. ${ }^{117}$ In a salutary corrective, Stuart Bell has recently demonstrated that there is very little contemporary evidence about the content and reception of the bishop of London's notorious Advent sermon of 1915 , possibly 'the most infamous sermon in Anglican history', ${ }^{118}$ which has been very widely billed and decried by historians (and sundry other commentators) as having urged the faithful to 'kill Germans', a lacuna that suggests that what was actually said at the time was considered either unremarkable or unexceptionable. ${ }^{119}$ In stark contrast, there is no doubt as to the significance and content of the sermon preached by Bishop Brent at St Paul's as part of the American service of dedication, and the numerous reports on his homily in the contemporary secular and religious press help us to grasp the broader context and potential impact of sermons of this era.

Although events and services to mark 'America Day' were held across the country, ${ }^{120}$ such was the scramble to attend the hastily-organised service at St Paul's that it proved impossible to accommodate all those who sought admission, ${ }^{121}$ with more than 10 ,ooo applicants seeking only 3,500

114 Church Times, 27 Apr. 1917, 360.

115 Adrian Gregory, The last Great War: British society and the First World War, Cambridge 2008, $15^{1}$.

${ }_{116}$ George Bedborough, Arms and the clergy (I914-19I8), London 1934; Abrams, Preachers present arms, passim.

${ }_{117}$ See, for example, Marrin, The last crusade, Wilkinson, The Church of England; A. J. Hoover, God, Germany, and Britain in the Great War: a study in clerical nationalism, New York 1989; and Aimee E. Barbeau, 'Christian empire and national crusade: the rhetoric of Anglican clergy in the First World War', AEH lxxxv (2016), 24-62.

${ }_{118}$ Gregory, The last Great War, 168.

119 Stuart Bell, 'Malign or maligned?: Arthur Winnington-Ingram, bishop of London, in the First World War', Journal for the History of Modern Theology xx (2013), $117-33$.

${ }_{120}$ Manchester Evening News, 20 Apr. 1917, 4; Dundee Courier, 21 Apr. 1917, 2.

121 The Times, 18 Apr. 1917, 5; Guardian, 19 Apr. 1917, 309. 
seats. ${ }^{122}$ In the event, what The Times described as 'A great and solemn service ... to mark the entry of the United States into the war for humanity' took place amidst thronging crowds and in glorious spring sunshine on Friday 20 April 1917. With the Union flag and the Stars and Stripes fluttering from hundreds of public buildings and private homes across London, worshippers in St Paul's Cathedral were joined by King George V and Queen Mary, by other members of the royal family, by various Allied dignitaries, and by the American ambassador, Walter Hines Page, and his entourage. Adding still further to the sense of drama, aeroplanes patrolled overhead and veterans of the American Civil War marched with their medals and their flags to the cathedral, "where the waiting crowd greeted them with enthusiasm'. ${ }^{123}$ Despite the grandeur of the occasion, the service itself was the essence of simplicity. What was billed as 'A Solemn Service to Almighty God on the occasion of the entry of the United States of America into the great war for freedom' comprised a hymn ('O God, our help in ages past'); the Lord's Prayer and responses; Psalms xlvi and cxliv; a Lesson (Isaiah xli.1-9); the Creed; 'some special responses and prayers' (including prayers for the king and President Wilson); the Grace, and then Julia Ward Howe's 'Battle Hymn of the Republic'. After Brent's sermon came another hymn ('Through the night of doubt and sorrow'); the Blessing (pronounced by Archbishop Davidson), and 'the American and the British National Anthems, played by the band and sung by choir and congregation'. ${ }^{124}$

As the centrepiece of the service, Brent's sermon reflected the heightened sense of hope and expectation felt by his audience in the spring of 1917, for with America's entry into the war exactly two weeks earlier, and the sensational capture of Vimy Ridge by the Canadian Corps on Easter Monday, it certainly seemed as though the New World was coming to the rescue of the Old. Furthermore, the recent Revolution in Russia and the downfall of the Czarist regime augured the demise of Europe's autocratic monarchies, and the advent of a prospectively liberal, democratic and pro-Allied regime in Russia served as a further sign that a new world order was emerging. Nevertheless, and while emphasising a common Anglo-American purpose, Brent was left with the difficult task of addressing very different constituencies among his mixed congregation. This he achieved by blending democratic zeal (articulated in Wilson's address to Congress of 2 April 1917, and his assertion that 'The world must be made safe for democracy') with large measures of patriotism, liberal theology, and ecumenism. In departures from what The Times considered to be 'the usual English practice', ${ }^{125}$ Brent commenced with a

122 Church Times, 27 Apr. 1917, 36o.

123 Derby Daily Telegraph, 21 Apr. 1917, 2; The Times, 21 Apr. 1917, 7.

124 The Times, 21 Apr. $1917,7$.

125 Ibid. 
prayer for the scattering of those nations that revelled in war, before preaching from the Apocrypha, his text being 2 Maccabees xiii.13-15. Again, and though the secular press saw this as an unusual choice, the Church Times provided a clarification, explaining that

Churchmen, knowing their Apocrypha, thought it most natural that he should call to our remembrance the spirit of those brave men who died long ago for their faith and their country, whose valour re-kindled the national spirit of Israel, and inspired the Jews with a new sense of the worth of their religion. ${ }^{126}$

Comparing their situation to that of Judas Maccabeus and his confederates arrayed against the pagan tyranny of the Seleucids, Brent embraced the whole assembly by stressing Anglo-American solidarity, portraying the occasion as marking 'a new epoch' wherein 'A great nation, well skilled in selfsacrifice, is standing by with deep sympathy and bidding God-speed to another great nation that is making its act of self-dedication to God.' And the affinity that Americans felt with England was, Brent claimed, immense:

We Americans have never been oblivious of the fact that the people of this country have been standing for the same principles which we love and for which we live. England, thank God! is the mother of democracy, and England's children come back to-day and pour all their experience, the experience of a century and a half of independent life, with gratitude at the feet of their mother. The aid which we gave her began in sympathy and work of compassion; but we have graduated from that ... and now we stand side by side with our fellows as common soldiers in a common fight. ${ }^{127}$

However, the next part of Brent's sermon was addressed to his American listeners, stressing the pacific nature of American democracy, quoting Abraham Lincoln, and pronouncing that 'Our war to-day is that we may destroy war ... The one thing to do with war is to hunt it to its death; and, please God, in this war we shall achieve our purpose.' ${ }^{128}$ Brent also sought to reconcile the claims of democracy and personal liberty, especially in light of the debates then raging over the introduction of the draft, a deeply controversial measure to which Wilson had committed himself in his address to Congress on 2 April and which, after his signing of the Selective Service Bill in May 1917, would sweep 2.8 million conscripts into the army. ${ }^{129}$ Conscious of the marginal relevance of this excursus to his British listeners, Brent explained, 'I say this because there are those within the reach of my voice who in a general way have dedicated their

\footnotetext{
126 Church Times, 27 Apr. 1917, 360.

127 http://anglicanhistory.org/asia/brent/commonwealth1917.html. ${ }^{128}$ Ibid.

129 Leonard Ayres, The war with Germany: a statistical summary, Washington, DC 1919,17 .
} 
lives to the service of God and humanity, but who in a moment may be called upon to take up arms and to face the bullets.' Returning to the theme of democracy, which he held to be coterminous with peace, Brent re-embraced the whole congregation by stressing the need for its universal application and the place of 'organized religion' as its spiritual essence. Developing this characteristically American perspective on democracy, Brent went on to quote John R. Mott, champion of world mission and the pre-eminent ecumenist of his day, on the overriding need for Christian unity in this moment of democracy's looming triumph:

It is, I think, becoming increasingly clear that that the question of world peace and of Christian reunion go together, for only the visible unity of the Church of Christ will be competent to remove the obstacles in the way of the establishment of His Kingdom of peace and righteousness and love.

Decrying an abiding a spirit of stubbornness - a selfish arrogance, even 'Prussianism' - in the Churches, Brent declared that 'The watchword of the Churches must be unity', before proceeding to the climax of his sermon:

I see a vision, I see a great movement, a movement not of men but of God, coming sweeping through this world of ours and gathering into its embrace all rightminded, true-hearted men. I see a united Church, a Church worthy of the residence of Jesus Christ among men, the shrine and instrument of His Spirit, a Church which will bring holiness and power to all the people of God.

Only when this vision was realised, so Brent averred, 'shall the Great War usher in the Great Peace'. ${ }^{130}$

As the centrepiece of the 'America Day' ceremonies, and of a service which The Times described as 'immeasurably significant to mankind', representing 'the dedication of the whole English-speaking world to the cause of righteousness' (sentiments which were also echoed by the Guardian), ${ }^{131}$ Brent's fanfare for a new era was splashed across newspapers in Great Britain and the United States, from the mighty New York Times to the minnows of the British provincial press. The text of the sermon, entitled 'The Commonwealth of Mankind', was also published in full in the Church Times and in pamphlet form by A. R. Mowbray. ${ }^{132}$ There was, inevitably, some scattered criticism. The Lichfield Mercury fretted that Brent had preached 'for about half-an-hour', and that 'sermons before Royalty are usually about half that length', while the Liverpool Daily Post worried that 'The very democratic sermon of Bishop Brent at St. Paul's is believed to

${ }^{130}$ http://anglicanhistory.org/asia/brent/commonwealth $1917 . \mathrm{html}$.

${ }^{131}$ The Times, 21 Apr. 1917, 7; Guardian, 26 Apr. 1917, 329.

132 Church Times, 27 Apr. 1917, 36o. 
have surprised the King.' ${ }^{133}$ They needn't have worried. Queen Mary noted that Brent had preached 'a fine sermon', ${ }^{134}$ while the king wrote in his diary:

We went to London with May [i.e. Queen Mary] \& drove with 4 horses to St Paul's Cathedral to attend the Dedication Service on America entering the war. A very impressive Service, Mama was there \& Mr and Mrs Page \& all the Americans in London. Bishop Brent (American) preached an excellent sermon. We drove back to [Buckingham Palace] large crowds of people all the way. ${ }^{135}$

Indeed, the general reaction to Brent's sermon was one of overwhelming approval and enthusiasm. While the Church Times applauded its 'burning words', memorable phraseology and welcome audibility, ${ }^{136}$ the Guardian felt that it had 'amply fulfilled the expectations of the vast congregation'. ${ }^{137}$ For its part, the secular press acclaimed Brent's presence as a preacher, even the Liverpool Daily Post noting that 'Dr. Brent is the possessor of a wonderful voice', and that his sermon 'will echo long in the heart of his hearers. In a voice of wonderful power, which could be heard at the west door, with the eloquence that springs from intense conviction, he preached upon the sanctity and meaning of democracy.' ${ }^{3}{ }^{8}$ Echoes of Brent's sermon were heard across the country in subsequent weeks. The bishop of Birmingham, Henry Russell Wakefield, invoked its words the following Sunday, stressing Brent's view that America's quarrel with imperial Germany was 'not a misunderstanding, it is an understanding'. ${ }^{139}$ That same day, at Silsoe in Bedfordshire, extracts from the sermon were read in the parish church during the morning and evening services, its pulpit having been seemingly hallowed by Brent's presence during his pre-war visits to another American ambassador, Whitelaw Reid. ${ }^{14^{\circ}}$ In another act of homage, a remarkable service took place at Rochdale's Castlemere Street Wesleyan Chapel on Sunday 29 April, one that was deliberately modelled on the service at St Paul's. Here, in a Nonconformist chapel in the depths of industrial east Lancashire, the 'Battle song [sic] of the Republic' was sung by 'a large congregation' and the Revd W. E. Sellers, a veteran commentator on religion and military affairs, ${ }^{1} 4^{1}$ invoked President Wilson's address to Congress on 2 April and Brent's sermon in

\footnotetext{
133 Lichfield Mercury, Friday 27 Apr. 1917, 3; Liverpool Daily Post, 28 Apr. 1917, 7.

134 Queen Mary's diary, entry for 20 Apr. 1917, Royal Archives, Windsor Castle, RA QM/PRIV/QMD. Used with the permission of Her Majesty the Queen.

${ }_{135}$ King George v's diary, entry for 20 Apr. 1917, ibid. RA GV/PRIV/GVD. Used with the permission of Her Majesty the Queen.

${ }_{136}$ Church Times, 27 Apr. 1917, 360.

138 Churh Thes, 27 Apr. 1917, 360. Guardian, 26 Apr. 1917, 329

Liverpool Daily Post, 21 Apr. 191 7, 4. ${ }_{139}$ Birmingham Daily Post, 23 Apr. 191 7, 3.

${ }^{14}{ }^{\circ}$ Bedfordshire Times and Independent, 27 Apr. 1917, 3.

${ }^{14}$ See W. E. Sellers, From Aldershot to Pretoria, London 1900; With our fighting men, London 1915; and With our heroes in khaki, London 1918.
} 
St Paul's Cathedral to show that 'the two together proved that we were fighting in a righteous conflict'. ${ }^{142}$

Culminating in his 'America Day' sermon, Brent's brief but eventful sojourn in Britain and France in the early months of 1917 cemented his position as the key ecclesiastical mediator between the United States and the British Empire for the remainder of the war. Returning to the United States at the end of April, Brent was called upon to preach to the Foreign Secretary's diplomatic mission to the United States in New York's Cathedral of St John the Divine on Sunday 13 May. ${ }^{143}$ Over the next few weeks, and before he returned to the Philippines, Brent continued to press the cause of Great Britain upon his adoptive countrymen and women. For example, at the end of May he spoke at a Unitarian festival in Boston, where his subject was 'The Spirit of Great Britain'. ${ }^{144}$ Again, in the middle of June, he told a reporter for the Chicago Daily Tribune that the military and financial burden carried by Great Britain had been colossal, and that victory now depended on it being transferred to American shoulders. ${ }^{145}$ As there is no evidence in Brent's papers of any collusion with Britain's War Propaganda Bureau at Wellington House, a body that had a considerable stake in religious propaganda aimed at Americans, ${ }^{14}{ }^{6}$ it is a testimonial to his profound personal commitment to AngloAmerican solidarity that Brent reprised and even expanded his role as a public mediator following his return to Europe, now as Bishop of Western New York, in December 1917. Initially armed with nothing more than a roving commission from the War Council of the American YMCA, over the next six months Brent undertook a self-appointed mission on the Western Front, namely that of 'creating good will between British and American' through public lectures given in the British and Canadian sectors. ${ }^{147}$ Significantly, and as Brent fully appreciated, this disposition could not be taken for granted in view of American sluggishness in entering the war, of strong anti-British elements in American society, and even of the unwelcome prolongation of the war that America's entry might portend. ${ }^{14^{8}}$ Even after Brent's ill-defined role on the Western Front had crystallised into that of 'Headquarters Chaplain. A.E.F.' by dint of his friendship with General John J. Pershing, ${ }^{149}$ Brent remained keen to lubricate inter-Allied relations and to further the cause of Anglo-American (and Canadian) solidarity.

${ }^{142}$ Rochdale Observer, 2 May 1917, 2.

143 New York Times, 14 May $1917,1$.

144 Christian Science Monitor, 24 May 1917, 11.

145 Chicago Daily Tribune, 16 June, 1917, 9.

${ }^{1} 4^{6}$ Thomas E. Hachey, 'British war propaganda and American Catholics, 1918',

Catholic Historical Review lxi (1975), 48-66.

147 Brent diary, entry for 22 Dec. 1917 , Brent papers, box 3 .

${ }^{14}{ }^{8}$ Brent diary, entry for 14 Dec. 1917 , ibid. box 2.

149 Stars and Stripes, 10 May 1918, 2. 
In addition to Brent's moral and pastoral concerns, the strains placed on the Anglo-American partnership (and, internally, on the military effort of the British Empire) by the problem of prostitution in Great Britain and France led him to recruit the support of Archbishop Davidson in pressing for inter-Allied conferences on the problem of venereal disease. ${ }^{15^{\circ}}$ Although two conferences held in London in May and in July 1918 proved fruitless, ${ }^{15^{1}}$ in June, and at the prompting of the American Admiral William S. Sims, Brent carried a public message of greeting from Pershing's AEF to the combined Anglo-American battle fleet at Scapa Flow in the Orkneys. Here, and amidst impressive scenes that would have warmed the heart of Alfred Thayer Mahan, Brent and his message became the focus of an outpouring of mutual admiration between the two largest navies in the world. ${ }^{152}$

Although the last five months of the war, and the commitment of ever larger American forces to France and to the front, absorbed Brent in his primary task of enlarging and co-ordinating chaplaincy provision in the $\mathrm{AEF}$, the services that he had rendered to the British Empire in being ' $\mathrm{a}$ constant and constructive interpreter between the United States and Great Britain' 153 did not go unrecognised. Among a slew of late war and post-war honours bestowed by the American, Belgian and French governments, Brent's worth to the British Empire was reflected in his being appointed Companion of the Bath 'In recognition of meritorious services rendered the Allied cause.' ${ }^{154}$ Significantly, this honour trumped those bestowed on the senior Anglican chaplain of the BEF, the greatly admired Bishop Llewellyn Henry Gwynne, who was appointed Companion of the Order of St Michael and St George and Commander of the newly created Order of the British Empire. ${ }^{155}$ Nor did Brent ever repent of his First World War career, notwithstanding the growing mood of regret and recrimination that came to sour perceptions of the war in the $1920 s$. If America's entry into the war in April 1917 served to mute criticism of his belligerent behaviour in Europe in the preceding weeks, Brent was taken to task over his wartime record in the post-war years. Although meriting only a single mention in the $25^{\circ}$-page dossier of clerical misbehaviour that was Ray H. Abrams's Preachers present arms,,$^{156}$ Zabriskie's 1947

\footnotetext{
${ }^{15^{\circ}}$ G. K. A. Bell, Randall Davidson, 2nd edn, London 1938, 891-7; http://hansard. millbanksystems.com/lords/1918/apr/1 1/soldiers-morals-and-health\#S5LVoo29Po_ 19180411_HOL_47.

${ }_{15^{1}}$ Brent diary, entry for 10 May, 11 July 1918, Brent papers, box 3; Bell, Randall Davidson, 896-7. $\quad{ }^{152}$ Brent diary, entry for 28 June 1918 , Brent papers, box 3 . 153 Kates, "Lo, I come to do thy will, O God"”, 268.

154 'General Headquarters American Expeditionary Forces', memorandum, 1918 , Brent papers, box 16 .

${ }_{155}$ Michael Snape, The Royal Army Chaplains' Department, 1796-1953: clergy under fire, Woodbridge-Rochester, NY 2008, $25^{6}$.
} 
biography acknowledged that 'Brent was criticized by various people for donning khaki, for giving way to hate against the Germans, for romanticizing war as a glamorous undertaking.' ${ }^{157}$ Nevertheless, these charges seem not to have bothered him unduly. In November 1928, a decade after the Armistice, only four months before his death, and as one of a delegation of American churchmen bearing messages of goodwill to Randall Davidson and his successor, Cosmo Lang, Brent preached a heartfelt sermon in Canterbury Cathedral entitled 'The Way to Peace'. Addressed to the 'MEN AND WOMEN OF ENGLAND', Brent praised the internationalism of the recent, war-renouncing Kellogg-Briand Pact but rebuked the complacency and isolationism of contemporary America. ${ }^{158}$ Pointing to the comparatively small sacrifices made by the United States during the war, which had served to make it 'the creditor nation of the world', ${ }^{159}$ Brent pointedly 'paid tribute to the magnitude of the contribution and the sacrifices made by the British Empire in the War, and set forth an ideal of larger loyalty to mankind together with national loyalty inspired by the spirit of brotherhood'. ${ }^{160}$

The wartime career of Charles Henry Brent is emblematic of the contemporary situation of the Protestant Episcopal Church. Patriotic, selfconfident and clearly aspiring to pre-eminence among America's Churches, its cultural capital and material resources at the turn of the twentieth century allowed it to punch well above its weight in national, colonial and foreign affairs. Partly for these reasons, it was also a growing force in the Anglican Communion, and Brent highlights the bonds that held this loose global network together. As Brent's conduct and sympathies throughout the First World War serve to illustrate, Anglicanism was still very much bound up with British and imperial identity. Furthermore, and even in America, where the Protestant Episcopal Church was well established and the 'hyphenate' label did not apply to those of English stock, it was often very much an emigrant tradition. Although the growth of the Communion in the latter half of the twentieth century, especially in the global South, has led to a forthright rejection of the historic 'AngloSaxon captivity' of the English Church, a century ago the Anglican Communion was bound together by blood and by culture as much as by a common faith. In the terrible and testing years of the First World War, when the Anglican Communion proved to be the prime agent of religious mobilisation in the cause of the British Empire (as, indeed, it was to be in the Second), to Anglicans and others such bonds appeared to be far more of an asset than they did a liability.

157 Zabriskie, Bishop Brent, 131.

${ }^{1} 5^{8}$ Christian Science Monitor, 26 Nov. 1928, 4 .

159 Chicago Daily Tribune, 27 Nov. 1928, 39. 160 The Times, 28 Mar. 1929, 19. 